(I) Alpine Flowers

36 Colour Plates from Watercolours specially prepared by Paul A. Robert. With Introductory Text by Prof. Dr. Carl Schroeter. (Art and Nature in Colour Series.) Pp. $12+36$ plates. (London : B. T. Batsford, Ltd., 1938.) 10s. net.

(2) A Gallery of Gum Trees

By A. W. D'Ombrain. Pp. $54+21$ plates. (London : H. K. Lewis and Co., Ltd., 1938.) 14s. $6 d$. net.

$\mathrm{H}^{\mathrm{H}}$ ERE are two beautiful examples of book production.

(1) The multi-coloured alpine flora of Switzerland lends itself easily to the painter in water-colours, and the many books printed and published in Switzerland containing reproductions of paintings of Swiss flowering plants are well known. Here we have thirty-six exquisite colour studies by Paul Robert reproduced by the world-famous 10 -colour Iris Press of the Polygraphische Gesellschaft Laupen, Berme. These have been collected together and an introductory text has been written by none other than one of the greatest authorities on the Swiss alpine flora, Prof. Karl Schröter, who has recently died (NATURE, 143, 365 ; 1939). Messrs. Batsford, the publishers of the English edition, are deserving of special commendation for offering this splendid collection at such a very modest price. The book is to be strongly recommended to botanists interested in alpine plants, artists, those interested in colour reproduction, and anyone keen on acquiring good books for his library.

(2) This descriptive collection of Australian gum trees is equally worthy of praise for its twenty-one beautiful coloured plates and good all-round production. It was set up and printed by the Australasian Medical Publishing Co., Ltd., which is to be congratulated on another real work of art. All the plates are reproductions of original paintings in water-colour executed by Miss Tydfyl Evans. Those living in Australia should have no difficulty in identifying any eucalypt if they have this book handy, and other botanists will get a very satisfactory idea of these peculiar trees from the text and illustrations. Any lover of a well-produced book, too, would consider himself fortunate in possessing a copy of this one.

\section{A Monograph of the British Neuroptera}

By Frederick James Killington. Vol. 2. (Ray Society Volume 123 for the Year 1936.) Pp. xii +306 +plates 16-30. (London: Bernard Quaritch, Ltd., 1937.) $25 s$.

T 'HIS volume completes the author's account of the British Neuroptera. It is in every way up to the standard of volume 1 , which was published in 1936 and has already been noticed in these columns. In volume 2 the subject-matter is concerned with the remainder of the family Hemerobiidæ together with the Chrysopidæ. Of the Heremerobiidæ it is noticed that the genus Hemerobius, as now understood, comprises eleven British species. Of the other genera of the family, Boriomyia with five British species, has undergone change of name. In the appendix to this volume the new genus Kimminsia is erected by the author to take its place. Of the rarer forms, Megalomus and Drepanopteryx, each with a single British species, are still comparatively little known. Some account of the metamorphosis of the first named is given, but as regards Drepanopteryx no progress has been made in our knowledge of its biology since a brief note by Standfuss published in 1910. Of the Chrysopidæ, fourteen British species are dealt with and these belong to the genera Chrysopt and Nathanica.

The volume is illustrated by fifteen plates (coloured and plain) and forty-seven text-figures. These are all well executed and reflect credit upon all concerned in their production. We congratulate Mr. Killington on the completion of a really excellent treatise.

A. D. I.

\section{Plant Physiology}

With Reference to the Green Plant. By Prof. Edwin C. Miller. (McGraw-Hill Publications in the Botanical Sciences.) Second edition. Pp. xxxi+120l. (New York and London: McGraw-Hill Book Co., Inc., 1938.) $45 s$.

7 HE first edition of this very comprehensive text1 book was favourably reviewed in NATURE of December 5, 1931, p. 952. In the second edition, about three hundred pages have been added and the price increased by ten shillings. This makes the price of the book rather excessive for the type of student for whom it is intended. All students reading for a university degree would find the book very useful, and research workers and other advanced students are offered an extensive bibliography at the end of each chapter. Subdivision of the text into large and small type will aid the student reading for a general degree. The questions inserted at the end of each chapter of the first edition have been omitted in this edition.

The whole text has been thoroughly revised and brought up to date, and much new material has been included.

\section{Inorganic Colloid Chemistry}

By Prof. Harry Boyer Weiser. Vol. 3 : The Colloidal Salts. Pp. viii +473. (New York : John Wiley and Sons, Inc.; London: Chapman and Hall, Ltd., 1938.) 30s. net.

THIS volume completes Prof. Weiser's treatise on inorganic colloid chemistry, and it is in every way a very satisfactory account of the subject with which it deals. The five parts treat of the colloid sulphates, halides, sulphides, ferro- and ferricyanides, and silicates. The treatment is essentially experimental, although the theories concerned receive adequate treatment. Full literature references are supplied. Among other general topics which come under review are the stability of sols and the mechanism of electrolyte coagulation, adsorption on ion lattices, adsorption indicators, the permeability of membranes, and the phenomena of thixotropy and rheopexy. Technical aspects receive careful attention.

The amount of information contained in the book is very large, yet the author has been able to produce a very readable text. 